Boletín de la Sociedad Geológica Mexicana

VOLUMEN 61, NÚM. 2, 2009, P. 155-165

\title{
Advances on Stratigraphy and Paleontology of the Muhi Quarry from the Mid-Cretaceous (Albian-Cenomanian) of Hidalgo, Central Mexico
}

\author{
Víctor M. Bravo-Cuevas ${ }^{1, *}$, Katia A. González-Rodríguez ${ }^{1}$, Carlos Esquivel-Macías ${ }^{1}$, \\ Christopher Fielitz ${ }^{2}$

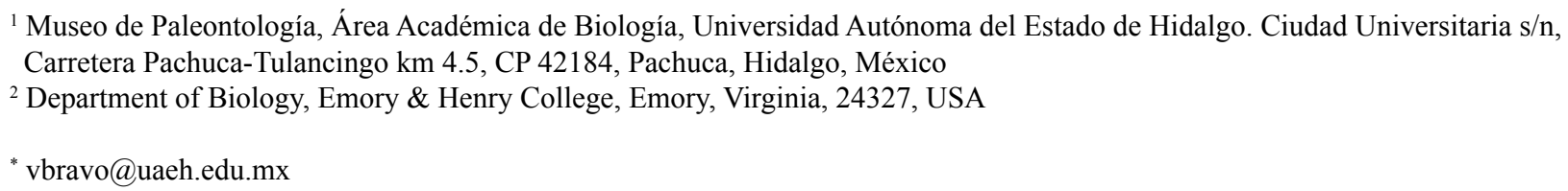

\begin{abstract}
The Muhi quarry of Zimapán Hidalgo, Central México, is one of the most important Cretaceous fish localities of the country because of the great diversity of fishes, and the significance of their record in America. Here we present some advances of the stratigraphy, including a litostratigraphic description, a generalized report of the marine fauna recovered, and the depositional environment of the outcrop. The sequence consists of a light gray mudstone/biomicrite, with chert forming nodules and/or thin layers, and additional marls are intercalated; the strata are assigned to La Negra Facies of the Mid-Cretaceous (Albian-Cenomanian) El Doctor Formation from northeastern Querétaro, south-central and northwestern Hidalgo (this report). The lithology and fossils are indicative of open sea shelf to deep shelf margin Standard Facies Zones, comparable to the Standard Microfacies Types SMF 2 (microbioclastic limestone) and SMF 3 (pelagic mudstone).
\end{abstract}

Keywords: stratigraphy, paleontology, Mid-Cretaceous, Hidalgo, Central México.

\section{Resumen}

La cantera Muhi de Zimapán, Hidalgo, centro de México, es una de las localidades cretácicas más importantes del país por la gran diversidad de peces que presenta y por su importancia en el registro fósil de América. Aqui se presentan datos adicionales acerca de su caracterización estratigráfica, incluyendo una descripción litoestratigráfica, un reporte generalizado de la fauna marina que porta, así como el ambiente de depósito en cual se desarrollo dicha secuencia. El afloramiento consiste en una secuencia de mudstone de color gris claro / biomicrita, con pedernal formando lentes y/o capas, así como intercalaciones de margas, que pertenecen a la Facies La Negra de la Formación El Doctor, mediados del Cretácico (Albiano-Cenomaniano) del noreste de Querétaro, región centro-meridional y noroccidental de Hidalgo (este reporte). La litología y los fósiles son indicativos de un ambiente de plataforma nerítica externa según la zonación de facies estándar, comparable a las microfacies estándar SMF2 (caliza microbioclástica) y SMF3 (mudstone pelágico).

Palabras clave: estratigrafia, paleontología, Cretácico, Hidalgo, Centro de México. 


\section{Introduction}

Cretaceous calcareous rock units of marine origin, outcrop in the northwestern corner of Hidalgo, central México (Fries, 1962, 1966; López-Ramos, 1972; Córdoba et al., 1992; Yta et al., 1999). In this region, there is a fossiliferous sequence known as Muhi quarry, a site which calcareous rock material has been commercially exploited for building purposes since 1950 by the citizens of Zimapán: the most important town of the region. Since 1998, we have collected more than 1,000 well-preserved specimens of invertebrates and fishes. The specimens are housed in the Museo de Paleontología of the Universidad Autónoma del Estado de Hidalgo (UAHMP).

The Muhi quarry is one of the most important Cretaceous fish localities from México, due to the great diversity and excellent preservation of fishes. The real diversity of the fauna is still incomplete because new taxa are discovered every year. Currently, we have more than 15 different groups of fish identified, and most species are new records for science.

New Cretaceous localities in México have been found in recent years, increasing the knowledge of fishes in the western Tethys Ocean and in North America. These localities include the famous Tlayúa quarry in Puebla of Albian age (Applegate, 1996; Applegate et al., 2006) the Albian El Espinal quarry in Chiapas State (Vega et al., 2006; AlvaradoOrtega and Ovalles, 2008); the Turonian-Maastrichtian quarries in the Guerrero State (Alvarado-Ortega et al., 2006); the Turonian Vallecillos quarry in Nuevo León State (Blanco-Piñón et al., 2001, 2002); the late Turonianearly Conacian El Rosario quarry in Múzquiz, Coahuila (Stinnesbeck et al., 2005); the Turonian La Mula quarry in Coahuila State (Blanco-Piñón and Alvarado-Ortega, 2005); Los Temporales (Turonian) quarries also in the Coahuila State (González-Barba and Porras-Múzquiz, 2009); and the Jaboncillos quarry of the Cenomanian-Turonian Boquillas Formation, in the Coahuila State (González-Barba and Espinosa-Chavez, 2005), among others; nevertheless this is the first Albian-Cenomanian fish locality reported in México and some of the fossils represent the first record for Western Hemisphere.

Given the above, it is clear that the Muhi quarry has an important paleontological significance; however, the stratigraphic description of this outcrop has not been studied in detail. Previously, González-Rodríguez and Bravo-Cuevas (2005) made the first report of the fauna and some paleoecological considerations of the deposit. In this report we present additional data on the lithology, age and correlation, depositional environment, and paleontology of the Muhi quarry. Additionally, we give some comments about its paleobiological significance.

\section{Material and methods}

The geological framework of the Zimapán area was based on López-Ramos (1972), Carrillo-Martínez and Suter-Cargneluti (1982), Córdoba et al. (1992), Consejo de Recursos Minerales (1992), and González-Rodríguez and Bravo-Cuevas (2005). The stratigraphy of the Muhi quarry sequence was based on field observations to the locality during 2007, as well as, petrographic description of 15 lithic hand samples and 15 rock thin sections evenly sampled at the lower, middle, and top portion of a reference measured section of $7.2 \mathrm{~m}$ thickness. The carbonate rock classification is that of Dunham (1962) and Folk (1968).

Paleontological summary on macrofossils is derived from previously published papers (González-Rodríguez, 2002; Vega et al., 2003; González-Rodríguez et al., 2005; González-Rodríguez and Bravo-Cuevas, 2005; Feldman et al., 2007; González-Rodríguez and Fielitz, 2008; Fielitz and González-Rodríguez, 2008), whereas it is presented additional and preliminary information on the microfossil record. Invertebrates and fish taxonomic descriptions are in progress, and fossil collecting is continuous.

\section{Geologic Setting}

The Muhi quarry is located in the Zimapán area, set in the northwest of the Mexican state of Hidalgo, between $20^{\circ} 40^{\prime}-20^{\circ} 50^{\prime} \mathrm{N}$ Lat and $99^{\circ} 15^{\prime}-99^{\circ} 25^{\prime} \mathrm{W}$ Long (Figure 1). The published geological information about this area is limited (Segerstrom, 1956, 1961; Fries, 1962, 1966; LópezRamos, 1972; Carrillo-Martínez and Suter-Cargneluti, 1982; Consejo de Recursos Minerales, 1992; Córdoba et al., 1992; Suter-Cargneluti et al., 1997; Yta et al., 1999). The only detailed stratigraphic descriptions were done by Carrillo-Martínez and Suter-Cargneluti (1982) and CarrilloMartínez (1997). For this reason, the summary presented below is based on these reports and supplemented by the observations of the authors.

Jurassic to Quaternary rock units crop out in the Zimapán area. The oldest unit is the Las Trancas Formation of late Jurassic (Kimmeridgian-Portlandian) (Segerstrom, 1956, 1961) to early Cretaceous (Hauterivian-Barremian) (Carrillo-Martínez, 1997) age. It consists of shale, dark yellow slightly metamorphic calcareous siltstone, light gray to dark gray micritic limestone set in thin strata, and rare layers of marl and black chert are intercalated. The thickness observed of the unit is around $200 \mathrm{~m}$, but the lower contact is not exposed.

According to Carrillo-Martínez and Suter-Cargneluti (1982) and Carrillo-Martínez (1997), sediments assigned to the El Doctor Formation include a $200 \mathrm{~m}$ thick sequence of light gray micritic limestone set in thin to medium bedded strata, black chert forming nodules or thin layers, and additional marls are intercalated. This rock unit unconformably overlies the Las Trancas Formation. Outside 


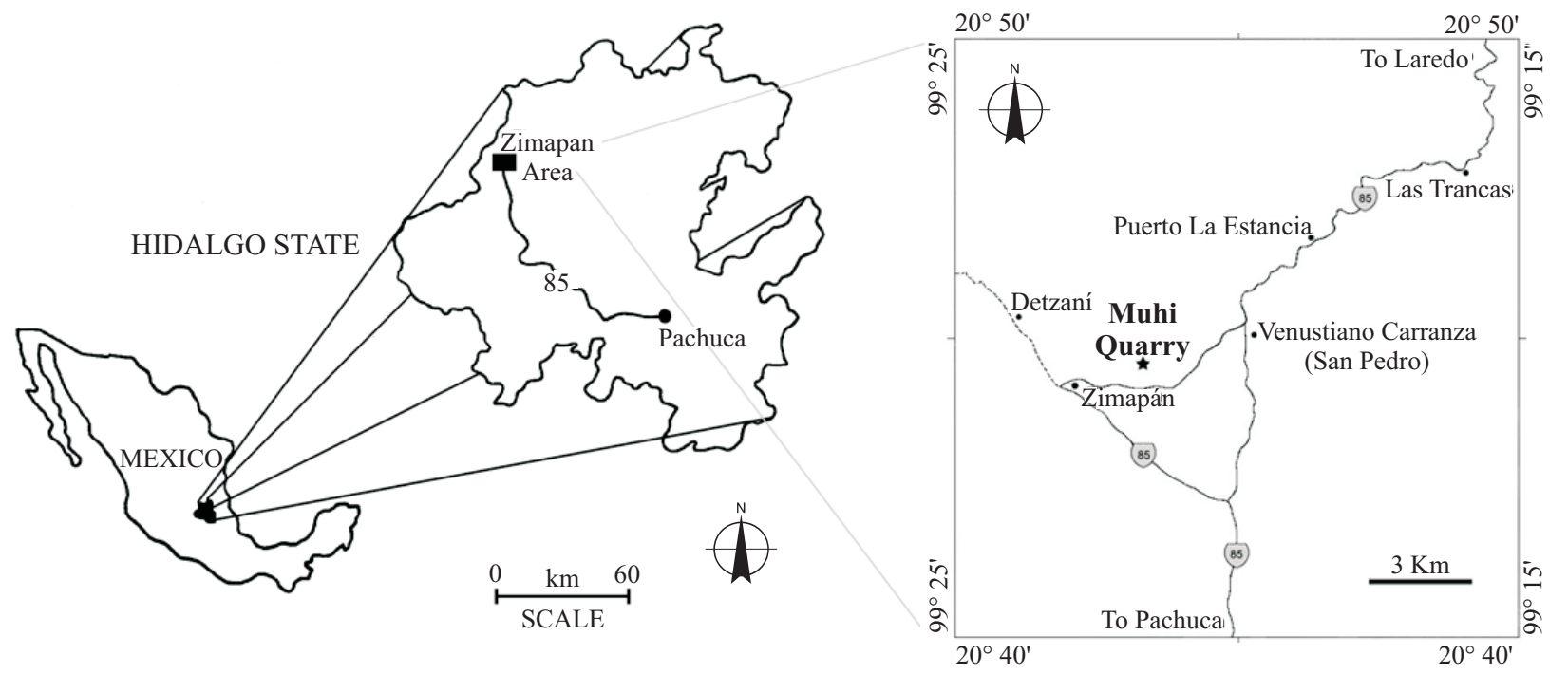

Figure 1. Index map showing the location of the Zimapán area and the Muhi quarry, set in northwestern Hidalgo, Central Mexico

of the Zimapán area, near the type locality at El Doctor in northeastern corner of Querétaro (also Central Mexico), the rudists Caprinulaidea gracilis and Mexicaprina sp. are present and suggest a Mid-Cretaceous (Albian-Cenomanian) age of the rock unit (Ward, 1979).

The Soyatal-Méndez Formation is Late Cretaceous (Turonian) in age (Fries, 1962), including a $200 \mathrm{~m}$ thick sequence of black to dark gray micritic limestone set in thin to medium - bedded strata, calcareous shale, marl, and chert. This unit unconformably overlies the Las Trancas and the El Doctor formations.

The Cenozoic sequence widely covers the Zimapán area. The El Morro Formation of late Eocene?-early Oligocene age (Simon and Mapes, 1957) is the oldest continental unit in the area, consisting of a $400 \mathrm{~m}$ thick conglomerate with limestone clasts derived from the underlying Cretaceous units, and epiclasts of andesitic to ultramafic composition in a matrix of shale and sand. The Las Espinas Formation includes a 300 to $400 \mathrm{~m}$ thick andesitic-basaltic lava flows and felsic tuffs. This unit is late Miocene in age, based on $\mathrm{K} / \mathrm{Ar}$ analyses of rock samples recovered near Zimapán; they have yielded an age of $9.0 \pm 0.3 \mathrm{Ma}$ (Cantagrel and Robin, 1979). The Quaternary is represented by alluvial, colluvial, and soil deposits.

\section{Stratigraphy of the Muhi Quarry}

\subsection{Lithology}

The Muhi quarry is located at $20^{\circ} 49^{\prime} 21.5^{\prime \prime} \mathrm{N}$ Lat and $99^{\circ} 15^{\prime} 38.3$ " W Long, about $3 \mathrm{~km}$ northeast of the Zimapán (Figure 1, Figure 2). A reference section of $7.2 \mathrm{~m}$ was measured, that includes gray to light gray, thin bedded, well indurated biomicritic and micritic limestone, which frequently bears chert forming nodules and/or chert bands, 3-10 cm thick; gray, yellowish and white bluish moderately indurated marls set in thin-bedded strata are also present. Scarce stylolitic suture planes are observed. Macrofossils have been recovered from five limestone strata, whereas microfossils are present in all sampling levels for thin section (Figure 3).

The petrographic description of rock thin sections indicates that the Muhi quarry sequence is a mudstone (Dunham, 1962) /biomicrite (Folk, 1968) with abundant calcispheres and nanoplankton, as well as, globigerinids and Gyroidinoides specimens; black chert layers formed by recrystallized radiolarians are also present (Figure 4). The lithology and microfossil record are indicative of open sea shelf to deep shelf margin Standard Facies Zones (Wilson, 1975), and comparable to the Standard Microfacies Types SMF 2 (microbioclastic limestone) and SMF 3 (pelagic mudstone) (Wilson, 1975; Flügel, 1978).

\subsection{Paleontology}

Fossil remains of ammonoids, crustaceans, echinoderms, and fishes, as well as numerous coprolites have been recovered from strata of the Muhi quarry (GonzálezRodríguez, 2002; Vega et al., 2003; González-Rodríguez et al., 2005; González-Rodríguez and Bravo-Cuevas, 2005; Feldman et al., 2007; González-Rodríguez and Fielitz, 2008; Fielitz and González-Rodríguez, 2008).

The specimens of ammonoids are uncommon and not well preserved, but they have been tentatively assigned to ?Mortoniceras sp. (Figure 5A). Crustaceans were recently 

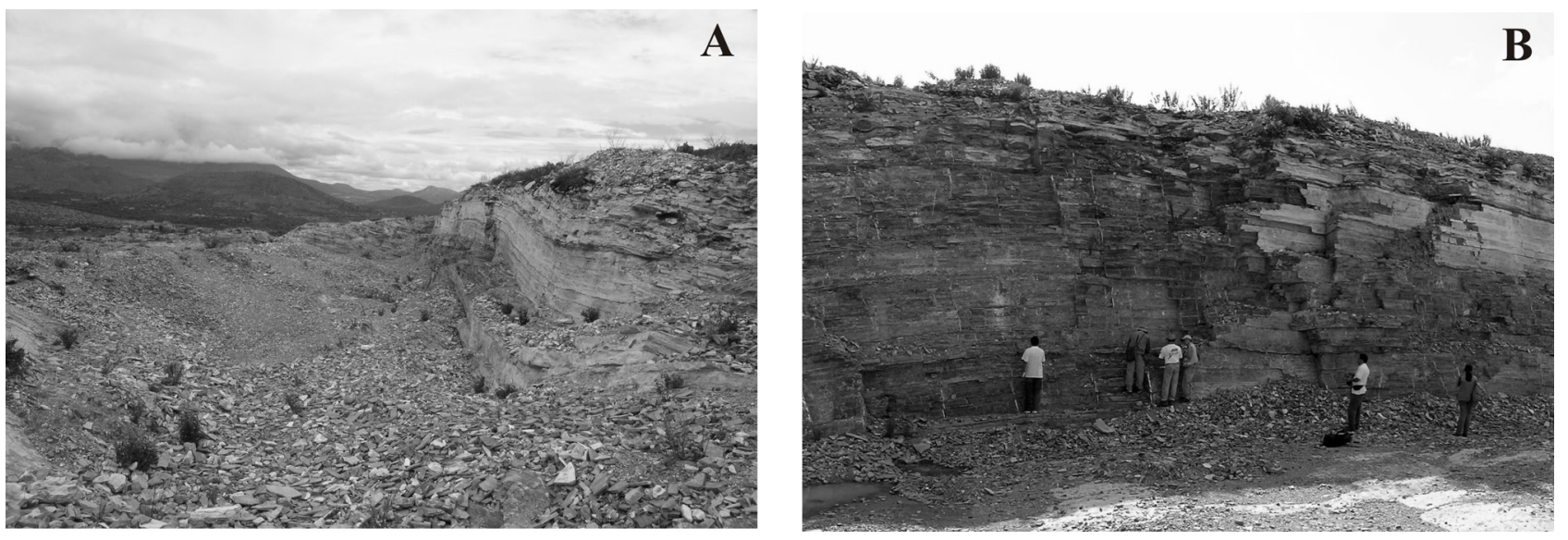

Figure 2. Panoramic views of the Zimapán area (A) and the Muhi quarry (B), northwestern Hidalgo, Central Mexico.

described by Feldman et al. (2007) and include Aeger hidalguensis n. sp. (Figure 5B) and Palinurus sp. Both taxa have been previously found in Late Cretaceous deposits of Eastern Tethys. A. hidalguensis represents the first record of Aeger in America; Aeger libanensis Roger, 1946 is reported in the Cenomanian deposits of Lebanon. Palinurus is the second report for America; the first record comes from the Albian deposits of Chiapas State, Southern México. Echinoderms consist of abundant planktonic comatulid crinoids (Figure 5C) that completely cover some strata, as well as abundant disarticulated echinoid spines (Figure 5D).

Fishes are the only vertebrates present in the quarry. They consist of chondrichthyans and neopterygians. Chondrichthyans include Squalicorax sp. (Figure 5E) and Ptychodus sp. (Figure 5F); rays have not yet been identified. González-Rodríguez and Bravo Cuevas (2005) reviewed records of Squalicorax and Ptychodus records from México and found that the Muhi specimens represent the first records for the Albian-Cenomanian of the country. There are reports of these genera in the Guerrero and Coahuila States (Alvarado-Ortega et al. 2006; GonzálezBarba and Espinosa-Chávez, 2005; González-Barba and Porras-Múzquiz, 2009) but the Muhi sharks are the oldest of Mexico.

Neopterygians comprise at least 12 different groups recognized at the moment: Lepisosteidae (Figure 5G), Aspidorhynchidae, Ichthyodectiformes, Megalopidae (Figure 5H), Pachyrhizontidae, Clupeomorpha, Ichthyotringidae (Ichthyotringa mexicana Fielitz and González Rodríguez, 2008) (Figure 5J, L), Dercetidae, Enchodontidae (Enchodus sp.) (Figure 5K), Halecidae, Euteleostei, and Acantomorpha (Muhichthys cordobai González Rodríguez and Fielitz, 2008) (Figure 5I).

The majority of fish groups present in the Muhi quarry had a wide distribution along the western Tethys Ocean during late Cretaceous, including other Mexican localities in the Coahuila, Nuevo León, and Guerrero states. Oldest Enchodus records are from lower Cenomanian of Israel,

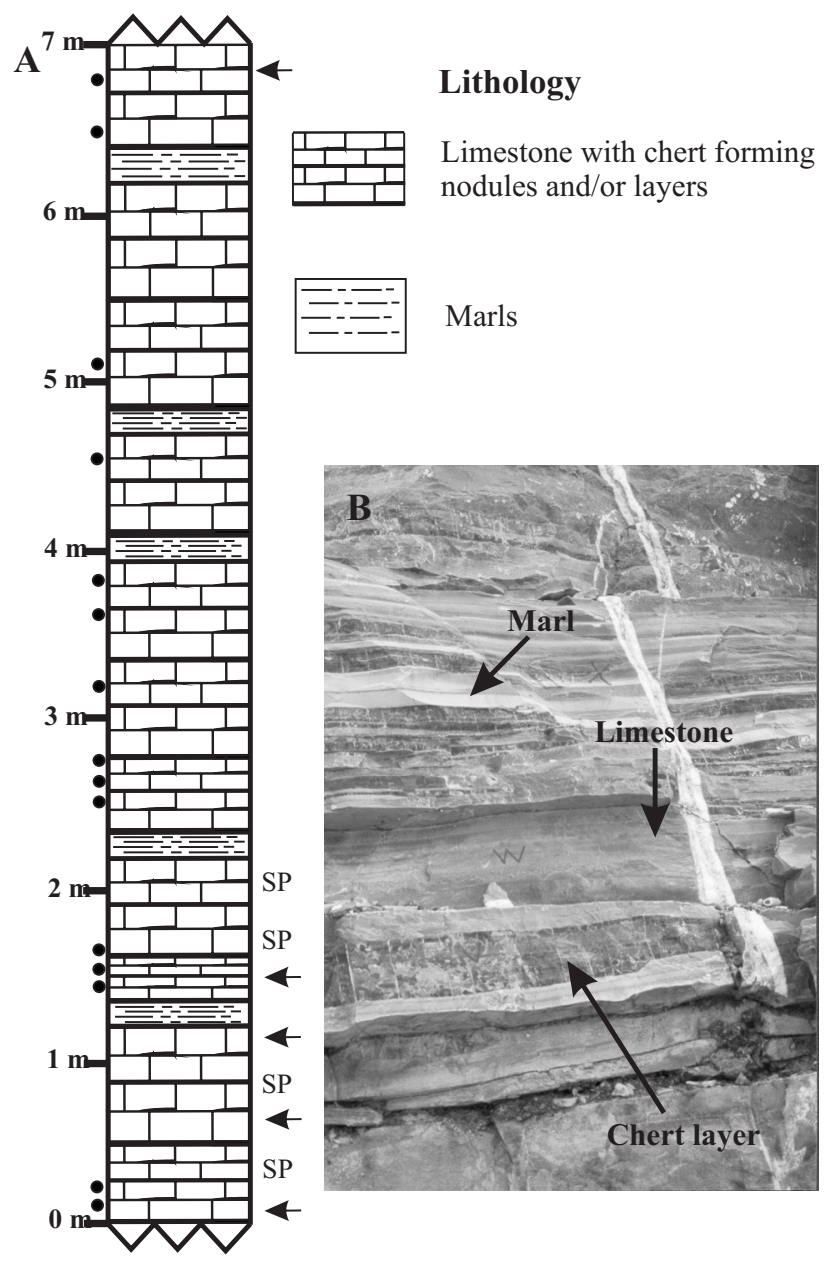

Figure 3. Stratigraphy of the Muhi quarry sequence from the MidCretaceous (Albian-Cenomanian) of northwestern Hidalgo, Central Mexico. A. Reference stratigraphic section which indicates rock thin section sampling levels (dots) and fish fossil levels (arrows); B. Close view of lithofacial variants of the Muhi quarry sequence. SP: stylolitic suture plane. 

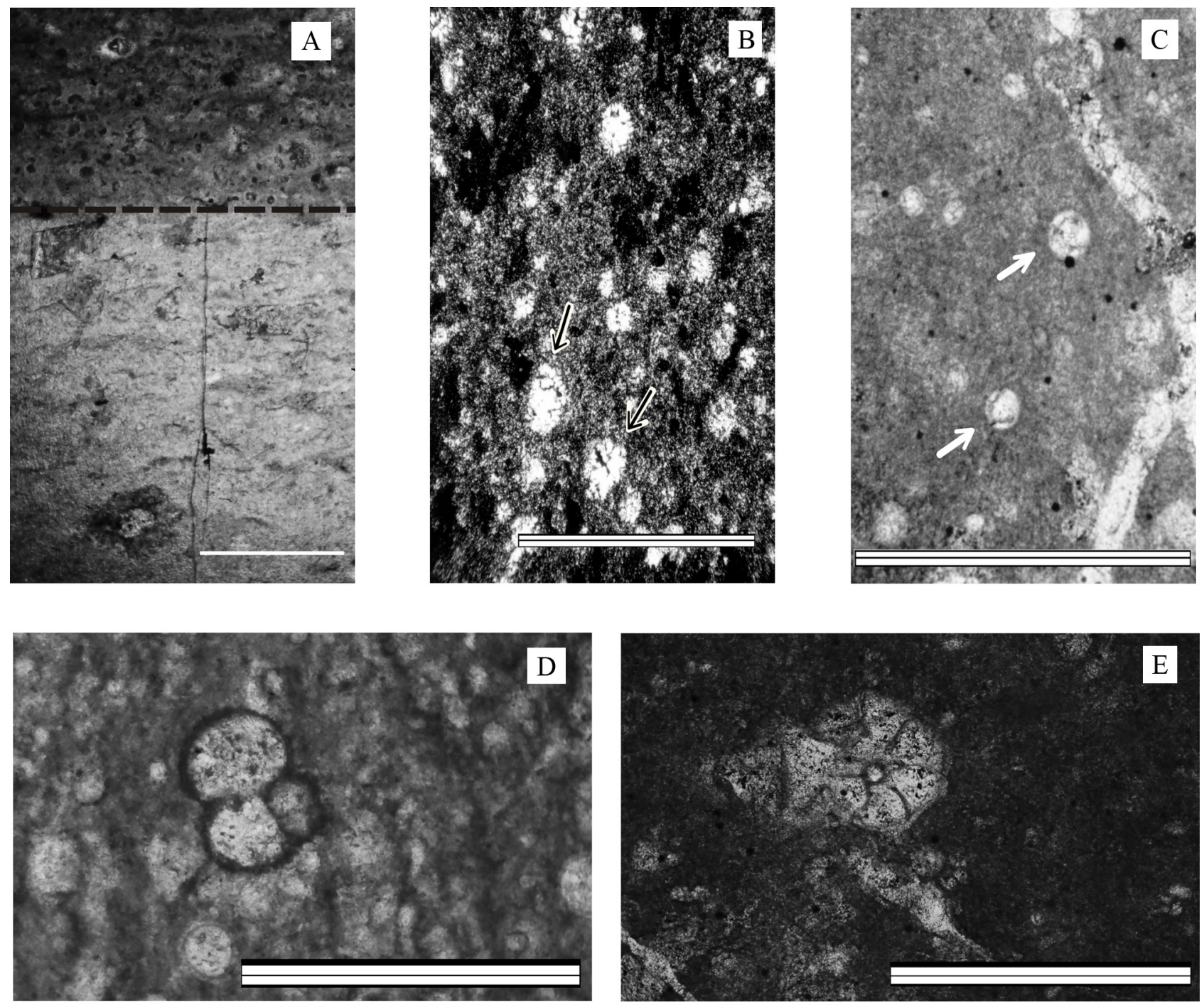

Figure 4. Petrography of the Muhi quarry sequence from the Mid-Cretaceous (Albian-Cenomanian) of northwestern Hidalgo, Central Mexico. A. The upper zone of dashed line is a mudstone (Dunham, 1962) / biomicrite (Folk, 1968), whereas the lower zone is a marl; B. Chert layer with recrystallized radiolarians (arrows indicating); C. Fossiliferous micritic limestone which bears calcisphere (arrows indicating); D. Planktonic foraminifera (globigerinid) in a mudstone matrix; E. Benthonic foraminifera Gyroidionides in a mudstone matrix. All photos are in polarized light. Scale bars equal 500 microns.

Adriatic region (Fielitz, 2004); Ichthyotringa was first reported from the Cenomanian of Lebanon and the new species of Muhi quarry Ichthyotringa mexicana Fielitz and González Rodríguez, 2008 represent the first report for the western Tethys; dercetids and halecoids have also their first appearances in the lower Cenomanian of the English Chalk and Lebanon (Goody, 1969); moreover, acanthomorphs first records are from Cenomanian beds of the English Chalk, Morocco, Lebanon, and Israel (Patterson, 1964, 1967, 1993).

Compared with the Late Cretaceous Mexican localities cited above, the Muhi quarry fishes are quite different. The quarry shares the presence of Anacoracidae and Ptychodontidae sharks, as well as some lamniforms, and many groups of teleosts such as clupeomorphs, ichthyodectiformes, enchodontids, pachyrhizontids, dercetids, and acanthomorphs with the mentioned localities, but it lacks tselfatiiforms, cimolichthyioids, and picnodontiforms taxa that are present in the El Rosario quarry in Múzquiz, Coahuila State (Stinnesbeck et al. 2005); the tselfatiiforms, pachycormids, nursallinids and some lamniform sharks of Vallecillo, Nuevo León (BlancoPiñon and Cavin, 2003); the tselfatiiforms of the La Mula quarry (Blanco-Piñón and Alvarado-Ortega, 2005); or the Cretoxyrhinidae sharks of the Mexcala Formation in the Guerrero State (Alvarado-Ortega et al. 2006). Moreover, lepisosteids, ichthyotringoids, aspidorhynchids, and megalopids are present in the Muhi quarry but, not reported in the other Late Cretaceous Mexican localities.

The taxonomic characterization of the Muhi quarry microfauna is in progress. González-Rodríguez and Bravo Cuevas (2005) reported the presence of calcispheres 


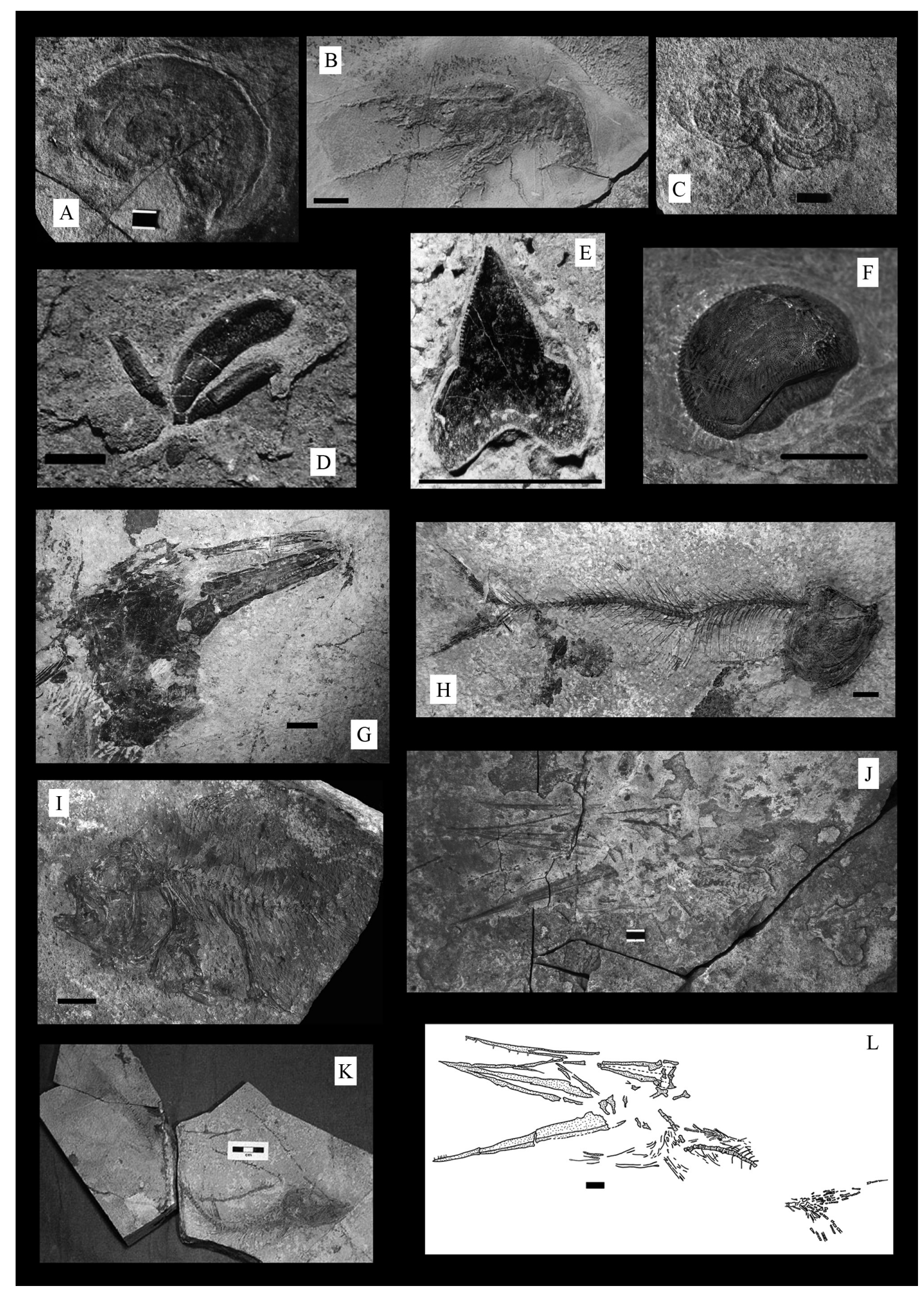

Figure 5. Macrofossil record of the Muhi quarry from the Mid-Cretaceous (Albian-Cenomanian) of northwestern Hidalgo, Central Mexico. A. ?Mortoniceras sp. (UAHMP-2032); B. Aeger hidalguensis Felman et al., 2007 (UAHMP-711); C. Planktonic crinoid (UAHMP-624); D. Partially articulated indeterminate echinoid spines (UAHMP-630); E. Squalicorax sp. tooth (UAHMP-747); F. Ptychodus sp. tooth (UAHMP-639); G. Lepisosteid head (UAHMP-2143); H. Megalopid fish (UAHMP-1063); I. Muhichthys cordobai González-Rodríguez and Fielitz, 2008 (UAHMP-2068); J., L. Ichthyotringa mexicana Fielitz and González-Rodríguez, 2008 (UAHMP-2067); K. Enchodus sp. nov. (UAHMP-679) is the most abundant fish of the quarry. Scale bars equal $1 \mathrm{~cm}$. 
assigned to Calcisphaerula sp. and Pithonella sp. However, nanoplankton, planktonic foraminifera (globigerinids), and benthonic foraminifera (Gyroidinoides sp.) are present, as well as, radiolarians are abundant forming black chert layers (Figure 4B-E).

\subsection{Depositional environment}

The Muhi quarry depositional environment is based on their lithology and fossil record, both macrofossils and microfossils.

\subsubsection{Lithology}

Based on the strata sequence of the 7.2 meters of micritic limestone exposed in the Muhi quarry, the following lithofacies are detected: a predominant mudstone facies, an intercalated chert facies, and a less common marl facies. The lithofacial variability is interpreted in terms of deposition occurring on the open sea shelf to deep shelf margin or basin margin of the El Doctor Formation according to the Standard Facies Zones of Wilson (1975). This suggests that the site of deposit received alternated neritic waters and open oceanic waters with occasionally influx of nearshore waters maybe during storms. The dark gray mudstone is typical of carbonate neritic platforms and oceanic basin waters (Wilson, 1975; Flügel, 1978), whereas sporadic marls together with unidentified shell fragments suggest incursions of rich terrigenous coastal waters (Figure 4A). Intercalated chert bands represent temporal pulses of pelagic waters mainly composed by recrystallized radiolarians (Figure 4B).

\subsubsection{Macrofossil record}

The Muhi quarry macrofossils could represent a paleocomunity that lived in well oxygenated waters of normal salinity at the limits of an open sea shelf and the deep shelf margin. Most of the fauna could live in the water column above the site of deposit, but others could come from near sites. On occasion, the Muhi deposit received pulses of shallower or deeper waters, as indicated by the lithology, which produced changes in the normal condition of the water leading to mass mortality. Changes in salinity could also affect the bottom of the site, which at least in occasions became hypersaline. Support of hypersaline bottoms is the lack of evidence of bioturbation and scavenging (Maisey, 1994; Martill, 1988) which is a probable phenomena observed in the Muhi quarry.

Examples of these inhabitants of the Muhi quarry are ammonites remains tentatively assigned to ?Mortoniceras sp., this Cretaceous ammonites were demersal forms that had stable buoyancy and inhabited the margin of the slope (Westermann, 1996). On the other hand, some Muhi quarry strata are completely covered by comatulids with their arms coiled; the Commatulida are stenohaline planktonic echinoderms that live in well oxygenated waters and are able to exist only in waters with a very narrow range of salt content (Hess, 2002). Given that, their abundance in many of the Muhi quarry strata suggests mass mortality due to changes in the concentration of oxygen and salt of the oceanic waters. Moreover, their coiled arms indicate dehydration caused by hypersaline waters (Seilacher et al., 1985). Crustaceans as Aeger hidalguensis and Palinurus sp. (Feldman et al., 2007) were benthonic organisms that could live near the deposit and were washed in the deposit through marine currents.

We believe that some fish could have lived at or near the site of deposit because of the presence of complete fish skeletons, abundant disarticulated fish bones, and numerous coprolites, but others could come from remote coastal or pelagic waters. Isolated skeletal parts such as skulls, fins, and backbones indicate flotation of fish prior to burial (Viohl, 1994). It is remarkable the occurrence of numerous small fish of different sizes belonging to almost all the different taxa recovered in the Muhi quarry. The majority of organisms move distances of meters or kilometers from juvenile to adult habitats. Adult habitats are considered to be areas where juveniles are not found and may encompass sub-adult staging areas (Gillanders et al., 2003). Therefore, the presence of juvenile fishes in the Muhi quarry, together with adult specimens makes the outcrop exceptional.

\subsubsection{Microfossil record}

The Muhi quarry sequence bears globigerinids, a group of stenohaline, planktonic foraminifera, typical of the euphotic zone (Molina, 2002), and much more common in the outer shelf (50 - $200 \mathrm{~m}$ depth) (Prothero, 2004). On the other hand, test morphology of the benthonic foraminifera Gyroidinoides is also indicative of an outer shelf environment with a typical euphotic depth $c a .100$ m (Prothero, 2004). Thus suggesting similar depositional conditions to the Muhi quarry sequence; the presence of abundant calcispheres in the considered strata supports this contention (see Monreal et al. 1997).

The Muhi quarry black chert layers evidence accumulation pulses of radiolarian organisms. In this regard, it should be noted that highest radiolarian abundances occur at the meeting point between the circulating currents surrounding two water masses, where oceanic upwelling brings up scarce silica from the deeper parts of the ocean and siliceous microorganisms rapidly utilize it (Prothero, 2004). Thus, is suggested that the depositional setting of the Muhi quarry sequence was controlled by influx of siliceous microfossils from pelagic waters.

\subsection{Age and correlation}

The age of the Muhi quarry strata hinges on its stratigraphic relationship with the other Mesozoic rock units that outcrop in the Zimapán area, and the biogeochronologic dating afforded by the marine fish fauna that it bears. Based on stratigraphic relationships of the Muhi quarry, this sequence is post-Las Trancas Formation (late Jurassic 
- early Cretaceous) and pre-Soyatal-Méndez Formation (late Cretaceous); thus the Muhi quarry sequence probably originated during Mid-Cretaceous (late early Cretaceous to early late Cretaceous). Fossil sharks support this age based on the first record of Squalicorax and Ptychodus in Albian-Cenomanian sediments of Texas, North America (Welton and Farris, 1993). Some neopterygian fish such as lepisosteids (Wenz and Brito, 1992; Cavin and Brito, 2001), pachyrhizontids (Cavin, 2008), and Clupeomorphs (Grande, 1985; Maisey, 1991) are recorded from Albian deposits around the world, but others had their first record during the early and middle Cenomanian, this is the case of dercetids (Goody, 1969), halecoids (Goody, 1969) Enchodus (Fielitz, 2004), Ichthyotringa (Fielitz and González-Rodríguez, 2008), and acanthomorphs (Patterson, 1964, 1967, 1993). Since, the Muhi Quarry would be restricted to an AlbianCenomanian age.

The Muhi quarry is geochronological correlative with the following Albian-Cenomanian rock units: the El Doctor Formation from northeastern Querétaro (Wilson et al., 1955; Carrasco, 1970, 1971) and south-central Hidalgo (Segerstom, 1961; Fries, 1962); the El Abra Formation from San Luis Potosí and Tampico (Garfías, 1915; Kellum, 1930; Aguayo-Camargo, 1998); and the Cuesta del Cura Formation from Nuevo León (Imlay, 1944; Ángeles-Villeda et al., 2005).

In summary, the Muhi quarry lithology and depositional conditions resemble that of the open sea shelf to deep shelf margin La Negra Facies of the El Doctor Formation from the Albian-Cenomanian of northeastern Querétaro (Wilson et al., 1955; Carrasco, 1970; Ward, 1979) and south-central Hidalgo (Segerstrom, 1956, 1961; Fries, 1962) respectively. Given that, the Muhi quarry strata would be regarded as part of the El Doctor Formation, indicating lithofacial lateral continuity - partially at least - of La Negra facies in northwestern Hidalgo.

\subsection{Comment on the Muhi quarry paleobiological} significance

Fishes are the best known fossils of the Muhi quarry. Fish assemblage is similar to that present in other Cenomanian localities of the Eastern Tethys Ocean, such as Namoura, Hakel and Haula in Lebanon, Jebel Tselfat, Kem Kem beds and Daura in Morocco, Ein-Yabrud in Jerusalem, English Chalk in England, and Comen in Slovenia. These localities correspond to different depth marine environments along the neritic platform, and comprise marine fauna as well as land plants and reptiles (Patterson, 1964, 1967, 1993; Chalifa, 1985, 1989; Raab and Chalifa, 1987; Cavin et al., 2001, 2005; Cavin and Dutheil, 1999, Forey et al., 2003). Even though the continuity of Mexican waters with the Western Interior Seaway of North America during Cenomanian, and the supraspecific taxa they share, such as sharks, aspidorhynchids, pachyrhizontids, ichthydectids, euteleosts, and acanthomorphs, which are present in
Colorado and Kansas in the United States, and the Black Hills, Pasquia Hills (Saskatchewan), and Alberta in Canada (Cumbaa et al., 2006; Cumbaa personal communication, 2009; Wilson and Murray, 1996, Wilson and Bruner, 2004), Muhi neopterygian fish species are different. Moreover groups as megalopids and lepisosteids are not reported in the Cenomanian Western Interior Sea localities.

According to the lithology of the deposit, the Muhi quarry is more like the Lebanese localities of Hakel and Haula where the fish beds consist of thin-bedded, siliceous limestone alternating irregularly with more massive limestone. Occasionally nodules and lenses of impure chert occur throughout the beds (Patterson, 1967). The microfauna consist of abundant radiolarians, moderately abundant pelagic foraminifera (Hedbergella) and rare benthonic foraminifera (textularids). The fish beds were deposited in small basins, only $250 \mathrm{~m}$ across, which Hückel (1970) interpreted as sinkholes formed by tectonic activity on the contemporary seafloor, at the outer margin of the continental shelf (Forey et al. 2003). The abundant wellpreserved fishes and crustaceans in some beds is evidence of mass mortality caused by some toxins released in water bloom conditions (Patterson, 1967).

On the other hand, both Hakel and Hajula, contain land plants and terrestrial fauna, a condition that does not occur in the Muhi Quarry. This suggests that the Muhi sequence was not so close to land masses. The resemblance of the lithology and affinity of the Muhi Quarry fish fauna with the Lebanese localities rather than with the Western Interior Sea of North America could be the result of the east-west vicariance and dispersal events, rather than north-south events that occurred during Late Cretaceous (Cavin, 2008). What seems evident is that most of the Muhi quarry fish and crustaceans represent new species of Late Cretaceous in Central Mexico, moreover some of them like Aeger hidalguensis and Ichthyotringa mexicana, constitute the first record for the western Tethys Ocean.

\section{Conclusions}

The Muhi quarry sequence consists of a mudstone/ biomicrite, which frequently bears chert forming nodules and/or thin layers; intercalated moderately indurated marls are also present. These strata bear diverse groups of invertebrates and fishes; furthermore, calcispheres, nanoplankton, radiolarians, as well as planktonic and benthonic foraminifera are present.

The Muhi quarry is Mid-Cretaceous in age, based on its stratigraphic relationships and the fish fauna record. This sequence is geochronological correlative with the La Negra Facies of the El Doctor Formation from the AlbianCenomanian of northeastern Querétaro and south-central Hidalgo; thus indicating lithofacial lateral continuity - partially at least - of La Negra facies in northwestern Hidalgo. 
The Muhi quarry lithology, macro and micro-fossils are indicative of open sea shelf to deep shelf margin Standard Facies Zones (Wilson 1975), comparable to the Standard Microfacies Types SMF 2 (microbioclastic limestone) and SMF 3 (pelagic mudstone) (Flügel, 1978).

The Muhi quarry deposit contains fish fauna that lived in central México during the Mid-Cretaceous (AlbianCenomanian). This fauna shows more affinities with the Cenomanian eastern Tethys Ocean localities than to those of the Western Interior Seaway of North America, thus suggesting east-west vicariance and dispersal events, rather than north-south events that occurred during late Cretaceous according to Cavin (2008).

\section{Acknowledgments}

We are indebted to anonymous reviewers for their comments and advice on the original draft of this report. We also thank the Universidad Autónoma del Estado de Hidalgo (UAEH) for supporting field work during 20062007, Proyecto: Estudio Paleontológico de la Caliza "El Doctor" en el Estado de Hidalgo. Special thanks to Mr. Jose Santiago Bautista and Mr. Arturo Palma Ramírez who elaborate the stratigraphic reference section, also we want to thank Mr. Jaime Priego Vargas who prepare the previous version of the Figure 3. At last but not to least we thank to Sergio and Ignacio Yañez, workers of the Muhi quarry for collecting fossil material since 1999.

\section{References}

Aguayo-Camargo, J.E., 1998, The Middle Cretaceous El Abra Limestone at its type locality (Facies, Diagenesis and Oil Emplacement), East Central México: Revista Mexicana de Ciencias Geológicas, 15(1), 1-8.

Alvarado-Ortega, J., Ovalles-Damián, E., 2008, Triplomystus applegatei, sp. nov. (Teleostei: Ellimmichthyiformes), a rare "triple armored herring" from el Espinal quarry (Early Cretaceous), Chiapas, southeastern Mexico: Journal of Vertebrate Paleontology, 28(1), $53-60$.

Alvarado-Ortega, J., Garibay-Moreno, L.M., Blanco-Piñón, A., GonzálezBarba, G., Vega-Vera, F., Centeno-García, E., 2006, Los fósiles de la Formación Mexcala (Cretácico Superior) en el estado de Guerrero, México: Revista Brasileira de Paleontología, 9(3), 261-272.

Angeles-Villeda, M.E., Hinojosa-Espinosa, J.J., López-Oliva, J.G., ValdézGonzález, A., Livas-Vera, M., 2005, Estratigrafía y microfacies de la parte sur del Cañon La Boca, Santiago, Nuevo León, México: Revista Mexicana de Ciencias Geológicas, 22, 272-281.

Applegate, S.P., 1996, An overview of the Cretaceous fishes of the quarries near Tepexi de Rodríguez, Puebla, México, in Arratia, G., Viohl, G. (eds.), Mesozoic Fishes: Systematics and Paleoecology: Verlag Dr. Friedrich Pfeil, München, Germany, 529-538.

Applegate, S.P., Espinosa-Arrubarrena, L., Alvarado-Ortega, J., Benammi, M., 2006, Revision of recent investigations in the Tlayúa quarry in Vega, F.J., Nyborg, T.G., Perrilliat, M.C., Montellano-Ballesteros, M., Cevallos-Ferriz, S.R.S., Quiroz-Barroso, S.A. (eds.), Studies on Mexican Paleontology: Series Topics on Geobiology, Kluwer Academic Publishers B.V., 24, 276-304.

Blanco-Piñón, A., Alvarado-Ortega, J., 2005, Fishes from La Mula quarries, a new Late Cretaceous locality from the vicinity of Múzquiz, Coahuila, NE Mexico, in Poyato-Ariza, F.J. (ed.), Fourth International Meeting on Mesozoic Fishes - Systematics, Homology, and Nomenclature, Extended Abstracts: Madrid, Servicio de Publicaciones de la Universidad Autónoma de Madrid/UAM Ediciones, 37-41.

Blanco-Piñón, A., Cavin, L., 2003, New Teleostei from the Agua Nueva Formation (Turonian), Vallecillo (NE Mexico): Comptes Rendus Palevol, 2, 299-306.

Blanco-Piñón, A., Stinnesbeck, W., López-Oliva, J.G., Frey, E., Adatte, T., González, A.H., 2001, Vallecillo, Nuevo León: una nueva localidad fosilífera del Cretácico Tardío en el Noreste de México: Revista Mexicana de Ciencias Geológicas, 18(2), 196-199.

Blanco-Piñón, A., Frey, E. Stinnesbeck, W., López-Oliva, J.G., 2002, Late Cretaceous (Turonian) fish assemblaje from Vallecillo, northeastern Mexico: Neues Jahrbuch für Geologie und Paläontologie, Abhandlungen, 225(1), 39-54.

Cantagrel, J.M., Robin, C., 1979, K-Ar dating on Eastern Mexican Volcanic Rocks-relations between the andesitic and the alkaline province: Journal of Volcanology and Geothermal Research, 5, 99-114.

Carrasco, B., 1970, La Formación El Abra (Formación el Doctor) en la Plataforma Valles-San Luis Potosí: Revista del Instituto Mexicano del Petróleo, (Julio), 97-99.

Carrasco, B., 1971, Litofacies de la Formación El Abra en la Plataforma de Actopan, Hidalgo: Revista del Instituto Mexicano del Petróleo, (Enero), 5-26.

Carrillo-Martínez, M., 1997, Hoja Zimapán 14Q-e (7), con Resumen de la Geología de la hoja Zimapán, estados de Hidalgo y Querétaro: México, D.F., Universidad Nacional Autónoma de México, Instituto de Geología, Carta Geológica de México serie 1:1,000,000.

Carrillo-Martínez, M., Suter-Cargneluti, M., 1982, Tectónica de los alrededores de Zimapán, Hidalgo y Querétaro, Libro Guía de la excursión geológica a la región de Zimapán y áreas circundantes, estados de Hidalgo y Querétaro, Hidalgo, México, in VI Convención Geológica Nacional: México, D. F., Sociedad Geológica Mexicana, $1-20$.

Cavin, L., 2008, Palaeobiogeography of Cretaceous bony fishes (Actinistia, Dipnoi and Actinopterygii), in: Cavin, L., Longbottom, A., Richter M. (eds.), Fishes and the break-up of Pangaea: Geological Society, London, Special Publications, 295, 165-183.

Cavin, L., Brito, P., 2001, A new Lepisosteidae (Actinipterygii: Ginglymodi) from the Cretaceous of the Kem Kem beds, southern Morocco: Bulletin Societé Géologique de France, 5, 661-670.

Cavin, L., Dutheil, D.B., 1999, A new Cenomanian ichthyofauna from southeastern Morocco and its relationships with other early Late Cretaceous Moroccan faunas: Geologische Mijnbouwkundige, 78, 261-266.

Cavin, L., Boudad, L., Duffaud, S., Kabiri, L., Le Loeuff, J., Rouget I., Tong, H., 2001, L'évolution paléoenvironnementale des faunes de poisons du Crétacé Supérieur du basin du Tafilalt et des régions avoisinantes (Sud-Est du Maroc): implications paléobiogéographiques, Rendus de l'Académie des Sciences, Sciences de la Terre et des Planètes, $333,677-683$

Cavin, L., Jurkovser, B., Kolar-Jurkovsek, T., 2005, The mid-Cretaceous fish assemblages from the Komen-Trieste plateau in Slovenia: its palaeogeographic and palaeoenvironmental significance, in PoyatoAriza, F. (ed.), Fourth International Meeting on Mesozoic FishesSystematics, Homology, and Nomenclature, Extended Abstracts: Servicio de Publicaciones de la Universidad Autónoma de Madrid/ UAM Ediciones, 67-68.

Consejo de Recursos Minerales, 1992, Monografía Geológico-Minera del Estado de Hidalgo, Publicación M-3e, Pachuca, Hidalgo: Secretaría de Energía, Minas e Industria Paraestatal, Subsecretaria de Minas e Industria Básica, 9 p.

Córdoba, D.A., Pedrazzini, C., López-Ávila, Silva-Mora, L., CastroGarcía, A. (comps.), 1992, Carta Geológica del Estado de Hidalgo, escala 1:250,000: México D.F., Universidad Autónoma del Estado de Hidalgo, Instituto de Geología, Universidad Nacional Autónoma de México, Secretaría de Educación Pública, 1 mapa. 
Cumbaa, S., Schröder-Adams, C. Day, R.C., Phillips, A., 2006, Cenomanian bonebed faunas from the Northeastern margin, Western Interior Seaway, Canada, in Lucas, S.G., Sullivan, R.M. (eds.), Late Cretaceous vertebrates from the Wester Interior: New Mexico, Museum of Natural History and Science Bulletin, 5, 139-155.

Chalifa, Y., 1985, Saurorhampus judeaensis (Salmoniformes: Enchodontidae), a new longirostrine fish from the Cretaceous (Cenomanian) of Ein-Yabrud, near Jerusalem: Journal of Vertebrate Paleontology, 5, 181-193.

Chalifa, Y., 1989, New species of Enchodus (Pisces: Enchodontoidei) from the Lower Cenomanian of Ein-Yabrud, Israel: Journal of Palaeontology, 63, 356-364.

Dunham, R.J., 1962, Classification of Carbonate rocks according to depositional texture: American Association of Petroleum Geologist, Memoir, 1, 108-121.

Feldman, R., Vega, F.J., Martínez-López, L., González-Rodríguez, K., González-León, O., Fernández-Barajas, M.R., 2007, Crustacea from the Muhi Quarry (Albian-Cenomanian), and a review of Aptian Mecochiridae (Astacidea) from Mexico: Annals of Carnegie Museum, 76(3), 135-144.

Fielitz, C., 2004, The phylogenetic relationships of the $†$ Enchodontidae (Teleostei: Aulopiformes), in Arratia, G., Wilson, M.V.H., Cloutier, R. (eds.), Recent Advances in the Origin and Early Radiation of Vertebrates: Verlag Dr. Friedrich Pfeil, München, Germany, 619-634.

Fielitz, C., González-Rodríguez, K., 2008, A new species of Ichthyotringa from the El Doctor Formation (Cretaceous), Hidalgo, México, in Arratia,G., Schultze, H.P., Wilson, M.V.H. (eds.), Mesozoic Fishes 4-Homology and Phylogeny: Verlag Dr. Pfeil, Munchen Germany, 373-388.

Flügel, E., 1978, Mikrofazielle untersuchungs-methoden von Valken: Berlin, Springer-Verlag.

Folk, L.R., 1968, Petrology of Sedmentary Rocks: Hemphills, Texas, United States of America, $170 \mathrm{p}$.

Forey, P.L., Yi, L., Patterson, C., Davies, C.E., 2003, Fossil fishes from the Cenomanian (Upper Cretaceous) of Namoura, Lebanon, Journal of Systematic Palaeontology, 1(4), 227-330.

Fries, C.J., 1962, Hoja Pachuca 14q-e(11), con resumen de la geología de la hoja Pachuca, estados de Hidalgo y México: México, D.F., Universidad Nacional Autónoma de México serie 1:100,000, 1 mapa con texto.

Fries, C.J., 1966, Resumen de la Geología de la Hoja Pachuca, Estados de Hidalgo y México: México, D.F., Instituto de Geología, Universidad Nacional Autónoma de México, Carta geológica de México, serie $1: 100,000$.

Garfias, V.R., 1915, The oil region of northeastern Mexico: Economical. Geology, 10, 1-195.

Gillanders, B.M., Able, K.W., Brown, J.A., Eggleston, D.B., Sheridan, P.F., 2003, Evidence of connectivity between juvenile and adult habitats for mobile marine fauna: an important component of nurseries: Marine Ecology Progress Series, 207, 2-81-295.

González-Barba, G., Espinosa-Chávez, B., 2005, Cenomanian-Turonian fish fauna from the Boquillas Formation at Jaboncillos, north-west Coahuila, Mexico, in Poyato-Ariza, F.J. (ed.), Fourth International Meeting on Mesozoic Fishes-Systematics, Homology, and Nomenclature, Extended Abstracts: Servicio de Publicaciones de la Universidad Autónoma de Madrid/UAM Ediciones, 105-107.

González-Barba, G., Porras-Múzquiz, H., 2009, Primer registro de Squalicorax (Lamniformes: Anacoracidae) en la cantera Los Temporales, Coahuila, México (abstract), in XI Congreso Nacional de Paleontología: Querétaro, Qro., México, Sociedad Mexicana de Paleontología, 29.

González-Barba, G., Coutiño-José, M.A., Ovalles-Damián, E., Vega, F.J., 2001, New Maastrichthian elasmobranch faunas from Baja California Península, Nuevo León and Chiapas States, Mexico (abstract), in III International Meeting on Mesozoic Fishes: SerpianoMonte San Giorgio, Suiza, 34.

González-Rodríguez, K. 2002. Paleoictiofauna de la Cantera Muhi en Zimapán, Hidalgo (abstract), in VIII Congreso Nacional de
Paleontología: Guadalajara, Jal., México, Sociedad Mexicana de Paleontología, 109.

González-Rodríguez, K.A., Bravo-Cuevas, V.M., 2005, Potencial fosilífero de la Cantera Muhi (Formación El Doctor: Albiano-Cenomaniano) de la región de Zimapán, Estado de Hidalgo: Paleos Antiguo, 1(1), 27-42.

González-Rodríguez, K., Fielitz, C., 2008, A new species of acanthomorph fish from the Upper Cretaceous Muhi Quarry, Hidalgo, Central México, in Arratia, G., Schultze, H.P., Wilson, M.V.H. (eds.), Mesozoic Fishes 4-Homology and Phylogeny: Verlag Dr. Pfeil, Munchen Germany, 399-411.

González-Rodríguez, K., Bravo-Cuevas, V.M., Esquivel-Macías, C., 2005, A Late Cretaceous locality from the State of Hidalgo, Central México (abstract), in II Congreso Latino-americano de Paleontología de Vertebrados: Río de Janeiro, Brasil, Serie Livros, 12, 128-129.

Goody, P.C., 1969, The relationships of Certain Upper Cretaceous teleosts with special reference to the Myctophoids: Bulletin of the British Museum (Natural History) Geology, London, Supplement 7.

Grande, L., 1985, Recent and fossil clupeomorph fishes with materials for revision of the subgroups of clupeoids: Bulletin of the American Museum of Natural History, 181, 231-372.

Hess, H., 2002, Upper Jurassic Solnhofen Plattenkalk of Bavaria, Germany, in Hess, H., Ausich, W.I., Brett, C.E., Simms, M.J. (eds.), Fossil crinoids: New York, Cambridge University Press, 216-224.

Hückel, U., 1970, Die Fischschiefer von Haquel und Hjoula in der Oberkreide des Libanon: Neues Jahrbuch für Geologie und Paläontologie Abhandlungen, 135, 113-149.

Imlay, R., 1944, Cretaceous formations of Central America and Mexico: Bulletin of the American Association of Petroleum Geologist, 28, 1077-1195.

Kellum, L.B., 1930, Similarity of surface geology in front ranges of Sierra Madre Oriental to subsurface in Mexican south fields: American Association of Petroleum Geologist, 140, 73-91.

López-Ramos, E., 1972, Carta geológica del Estado de Hidalgo, escala 1:500,000: México, D.F., Instituto de Geología, Universidad Nacional Autónoma de México, serie de Cartas Geológicas Estatales, 1 mapa.

Maisey, J., 1991, Santana Fossils. An Illustrated Atlas: T.F.H. Publications, Inc., USA, 459 p.

Maisey, J., 1994, Predator-prey relationships and trophic level reconstruction in a fossil fish community: Environmental Biology of fishes, 40, 1-22.

Martill, D., 1988, Preservation of fish in the Cretaceous Santana Formation of Brazil: Palaeontology, 31(1), 1-18.

Molina, E., 2002, Foraminíferos planctónicos: Globigerinina, en Molina, E. (ed.), Micropaleontología: Zaragoza, España, Prensas Universitarias de Zaragoza, 109-140.

Monreal, R., Montijo-González, A., Almazán-Vázquez, E., 1997, Guía para el estudio petrográfico de rocas carbonatadas: Sonora, Talleres gráficos de la Universidad de Sonora.

Patterson, C., 1964, A review of Mesozoic acanthopterygian fishes, with special reference to those of the English Chalk: Philosophical Transactions of the Real Society of London, Serie B 247, 213-482.

Patterson, C., 1967, New Cretaceous berycoid fishes from the Lebanon: Bulletin of the British Museum (Natural History) Geology, 14(3), 69-109.

Patterson, C., 1993, An overview of the early fossil record of acanthomorphs: Bulletin of the Marine Science, 52(1), 29-59.

Prothero, D.R., 2004, Bringing fossils to life: New York, McGrawHill.

Raab, M., Chalifa, Y., 1987, A new enchodontid fish genus from the Upper Cenomanian of Jerusalem, Israel: Palaeontology, 30, 717-731.

Roger, J., 1946, Les invertébres des couches à poissons du Crétacè supérieur du Liban: Mémoires de la Societé Géologique de France, $23,1-92$.

Segerstrom, K., 1956, Estratigrafía y Tectónica del Cenozoico entre México, D. F. y Zimapán, Hidalgo, in Maldondo-Koerdell, M. (ed.), Estratigrafía del Cenozoico y del Mesozoico a lo largo de la carretera entre Reynosa, Tamaulipas y México, D. F., Tectónica de la Sierra Madre Oriental (Guía de Excursiones), en XX Congreso Geológico 
Internacional, México, D.F., 311-322.

Segerstrom, K., 1961, Geología del suroeste del Estado de Hidalgo y del Noroeste del Estado de México: Boletín de la Asociación Mexicana de Geólogos Petroleros, 3(3-4), 147-168.

Seilacher, A., Reif, W.E., Westpha, F., 1985, Sedimentological, ecological and temporal patterns of fossil lagerstäten: Philosophical Transactions of the Royal Society of London, 311, 5-24.

Simons, F.S., Mapes, E., 1957, Geología y yacimientos minerales del distrito minero de Zimapán, Hidalgo: Boletín del Instituto Nacional de Investigaciones de Recursos Minerales, 40, $282 \mathrm{p}$.

Stinnesbeck, W., Ifrim, C., Scmidt, H., Rindfleisch, A., Buchy, M.C., Frey, E., González-González, A.H., Vega, F.J., Cavin, L., Keller, G., Smith, K.T., 2005, A new lithographic limestone deposit in the Upper Cretaceous Austin Group at El Rosario, county of Múzquiz, Coahuila, northeastern México: Revista Mexicana de Ciencias Geológicas, 22(3), 401-418.

Suter-Cargneluti, M., Contreras-Pérez, J., Ochoa-Camarillo, H., 1997, Structure of the Sierra Madre Oriental fold-thrust belt in east-central México, Libro-Guía de las excursiones geológicas, Excursión 2, in II Convención sobre la Evolución Geológica de México y Recursos Asociados, Pachuca, Hidalgo: Universidad Autónoma del Estado de Hidalgo e Instituto de Geología de la Universidad Nacional Autónoma de México, 45-63.

Vega, F.J., García Barrera, P., Coutiño, M., Nyborg, T., Cifuentes-Ruiz, P., González-Rodríguez, K., Martens, A., Delgado, C.R., Carbot, G., 2003, Early Cretaceous arthropods from plattenkalk facies in México: Contributions to Zoology, 72(2-3), 187-189.

Vega, F., García-Barrera, P., Perrilliat, M.C. Coutiño, M.A., Mariño-Pérez, R., 2006, El Espinal, a new plattenkalk facies locality from the Lower Cretaceous Sierra Madre Formation, Chiapas, southeastern Mexico: Revista Mexicana de Ciencias Geológicas, 23(3), 323-333.

Viohl, G., 1994, Fish Taphonomy of the Solnhofen Plattenkalk-An approach to the reconstruction of the paleoenviroment: Geobios, M.S., 16, 81-90.

Ward, J.A., 1979, Stratigraphy, depositional environments, and diagenesis of the El Doctor platform, Querétaro, Mexico: Binghampton, State University of New York, PhD. Thesis.
Welton, B.J., Farris, R.F., 1993, The collector's guide to fossil sharks and rays from the Cretaceous of Texas: Lewisville, Texas, Before Time, $204 \mathrm{p}$.

Wenz, S., Brito, P., 1992, Premierè découverte de Lepisosteidae (Pisces, Actinopterygii) dans le Crétacé inférieur de la Chapada do Araripe (N-E du Brésil), Conséquences sur la phylogénie des Ginglymodi: C.R. Académie des Sciences Paris, 314(2), 1519-1525.

Westermann, G.E.G., 1996, Ammonoid life and habitat, in Landman, N. H., Tanabe, K., Davis, R.A. (eds.), Ammonoid Paleobiology: New York, Plenum Press, 607-707

Wilson, J.L., 1975, Carbonate Facies in Geologic History: New York, Springer-Verlag.

Wilson, B.W., Hernández, J.P., Meave, E.T., 1955, Un Banco Calizo del Cretácico en la parte Oriental del Estado de Querétaro, México: Boletín de la Sociedad Geológica de México, XVIII(1), 1-10.

Wilson, M.V.H., Murray, A., 1996, Early Cenomanian acanthomorph teleost in the Cretaceous Fish Scale Zone, Albian/Cenomanian boundary, Alberta Canada, in Arratia, G., Viohl, G. (eds.), Mesozoic Fishes: Systematics and Paleoecology: Verlag Dr. Friedrich Pfeil, München, Germany, 369-382.

Wilson, M.V.H., Bruner, J.C., 2004, Mesozoic fish assemblages of North America, in Arratia, G., Tintori, A. (eds.), Mesozoic Fishes 3: Systematics, Paleoenvironments and Biodiversity: Verlag Dr. Friedrich Pfeil, München, Germany, 575-595).

Yta, M.J., Galván, C.R., Esparza, C., 1999, Carta Metalogénica-GeológicaEstructural del Estado de Hidalgo: Pachuca, Hidalgo, escala 1:250,000: Consejo de Recursos Minerales, Secretaria de Comercio y Fomento Industrial, 1 mapa.

Manuscript received: February 27, 2009.

Corrected manuscript received: June 16, 2009.

Manuscript accepted: June 21, 2009. 